\title{
Moral Cognitive Development of Primary School Students in Thematic Integrated Curriculum
}

\author{
Rarasaning Satianingsih. \\ University of PGRI Adi Buana \\ Surabaya, Indonesia \\ rarasaning.setyaningsih@gmail.com \\ Bunyamin Maftuh \\ Indonesia University of Education \\ Bandung, Indonesia \\ bunyamin.maftuh@gmail.com
}

\author{
Ernawulan Syaodih. \\ Indonesia University of Education \\ Bandung, Indonesia \\ ernawulansy@gmail.com
}

\begin{abstract}
This study aims to determine the moral cognitive development of elementary school students through learning based on cognitive models of morals in the integrated thematic curriculum (BKMT). The research method used is the quasi experiment with the one group pretest-post-test design. The sample of this research is students of class V SD Ketabang Surabaya which amounts to 37 people. The instrument used to collect the data in the study was the Moral Reasoning Test compiled by Kohlberg with modifications. The data analysis technique used in this research is descriptive. The results of this study indicate that there is an increase in the level of cognitive development of learners significant moral on the application of cognitive-based moral learning model in the integrated thematic (K-13)
\end{abstract}

Keywords - Cognitive Moral, learning based on cognitive models of morals and the integrated thematic curriculum

\section{INTRODUCTION}

The moral cognitive development according to [1] can be improved through a learning model that emphasizes moral cognition. The moral learning model that emphasizes cognitive development is not just to open or shape the reasoning of a person / learner, or simply to familiarize the learner with the existence of certain issues, values or values of dimension moral dilemma, but is part of an effort to Learners go beyond the stage of moral cognitive development that has been achieved and subsequently to achieve higher stages [2], [3]

Based on the perspective of moral cognitive learning, the researcher believes that moral cognitive learning becomes very important to be implemented, especially in basic education. This is so that learners actually internalize moral values and make those values part of themselves. It takes skills to enable learners to use these moral values in their daily activities. Learners should be able to see the behavioral effects, their choices, and be able to develop the skills of making environmentally conscious moral decisions [4], [5].

In constructing, presenting, and performing moral judgments, learners experience a process of moral cognitive development (Piaget and Kohlberg). [3], [5], [6], [7] This suggests that moral cognitive develops through a gradual cognitive sequence of reorganization. Each stage has identifiable forms, patterns, and organizations. This stage is not only a process that requires a change of cognitive structure, but also depends on cognitive development, and stimulation of the social environment [5], [6], [7].

Learning by presenting various experiential activities on moral values can help learners in (1) think and reflect on different moral values and practical implications when expressing those values in relation to oneself, others, and society. (2) Deepening understanding, motivation, and responsibility when determining positive personal and social choices. (3) To inspire learners to choose personal, social, and spiritual moral values and to be aware of practical methods in developing and deepening those moral values [8], [9].

The curriculum 2013 (K-13) with a scientific approach emphasizes the balance between attitudes, skills, and knowledge to build soft skills and hard skills of learners [10], [11], [12] In the learning process at the primary school the preferred or dominant attitude aspect is introduced, taught, and or exemplified in the child; Followed by the realm of skill; The last domain of knowledge with the least share [13], [6]. Learning is conducted based on empirical concepts, theories, and facts that can be accounted for. The scientific learning process touches on three domains: the attitude to "know why", the knowledge to "know what", and the skills to "know how" [12].

Nevertheless, in constructing their moral values, presenting and carrying out moral judgments learners do not passively carry out the available scripts, but they creatively to construct, to produce, to reproduce, to present, and do moral judgment in themselves [3], [5], [6], [14], [15], [16]. In this study, moral cognitive development is not only understood as an individual or group action in impression management but also arises as an individual and/or group response to the moral behavior of others in certain social, cultural, and norm contexts [17]. Thus, the moral judgment ability of learners which is one embodiment of moral cognitive is understood as a result of complex and 
complex modifications that reflect the struggle between learners with contextualization (stage) and impression management [17], [18].

Updating the learning process can be done by developing a model of cognitive-based moral learning in an integrated thematic curriculum with an emphasis on scientific activity and direct experience of living values activity so that students can construct their moral judgment [3].

Based on the phenomena studied and the theoretical perspectives used, the research problem can be formulated as "How is the moral development of primary school students through the application of cognitive-based learning model in an integrated thematic curriculum (K-13)?"

This study aims at producing not only individual toward "knowing" but also individual "being" moral values in character education in schools that emphasize moral cognitive. In addition, this study focuses on the importance of moral cognitive learners to determine moral decisions in everyday life. The development of an integrated thematic cognitive model encourages learners to know what, know-how, and know why in making moral decisions.

The updates generated in this study are the renewal of the system and the learning process that is the cognitive-based learning model in the integrated thematic curriculum with emphasis on scientific activity and direct experience of the living values activity so that students can construct their moral judgment. This method should be taught to children from an early age in order to form a habit that will someday form them into individual "being," i.e, human beings who do what they know to be true.

\section{METHOD}

The method in this research is the quasi experiment with the one group pretest-post-test design [19] and can be described in Table I.

TABEL I. RESEARCH DESIGN

\begin{tabular}{|c|c|c|c|}
\hline Class & Pretest & Treatment & $\begin{array}{c}\text { Post- } \\
\text { test }\end{array}$ \\
\hline Experimental & $\mathrm{Y} 1$ & $\mathrm{X}$ & $\mathrm{Y} 2$ \\
\hline
\end{tabular}

Information :

Y1: Pretest in the experimental class

Y2: Post-test in the experimental class

$\mathrm{X}$ : Treatment, that is the application of learning model based on moral cognitive development in experiment class.

The subjects of the study were students of class V SDN Ketabang Surabaya which consisted of 37 people. The implementation of this research was adapted to the theme of learning that was being pursued so as not to disrupt the activity of teaching and learning process.

The instrument used to collect data in the research was the Moral Cognitive Development Tests developed by Kohlberg with modifications. This test was taken from an interview guide developed by Kohlberg in the form of short stories containing moral issues to solve. The purpose of the use of this test was to disclose the respondent's reasoning about what action should be done if the respondent was in a situation like a story. This answer was an indicator at which the stage moral reasoning respondents where.

This research used describing analysis systematically, deepening and accurately in all of the phenomena, situs and characteristics of research substantial. This method used action analysis or student behavior and effort to enhancing moral cognitive development student (understanding and moral judgment ability of student). Base on question research and aim this research, descriptive analysis is used to analyze:

\section{Moral cognitive analyzing test}

\section{1) Mean analyzing}

Mean analyzing to describe an average score of moral cognitive. This analysis to get describing tendency moral cognitive or reasoning students.

\section{2) Percentage analysing}

Percentage analyzing to describe cognitive moral test score. This analysis to get describing tendency percentage of moral cognitive or reasoning students. Based on a number of participants in every step is score test. Thus, score test was used to analyzing to answer problem research then percentage calculated.

\section{RESULTS AND DISCUSSION}

The stage of moral cognitive development students grade $\mathrm{V}$ SD Ketabang Surabaya as a whole showed an improvement in the stage of moral cognitive development. The following is the recapitulation of improvement moral cognitive development learners by using the model of cognitive-based moral learning in the integrated thematic curriculum.

The following will be presented results analysis data of cognitive tests of moral tests learners in a limited test. Table II and Table 3 are cognitive reasoning student's traits at what stage of development. Overall, results of cognitive moral test learners in the BKMT learning model have improved.

TABLE II. RECAPITULATION OF MORAL COGNITIVE DEVELOPMENT OF LEARNERS

\begin{tabular}{|c|c|c|}
\hline $\begin{array}{c}\text { Name of Elementary } \\
\text { School }\end{array}$ & Pretest & Posttest \\
\hline SD Ketabang & 3.05 & 4.04 \\
\hline
\end{tabular}

TABLE III. PERCENTAGE AND FREQUENCY OF STUDENT'S MORAL COGNITIVE IN LIMITED TEST

\begin{tabular}{|c|c|c|c|c|c|c|c|c|c|}
\hline \multirow{2}{*}{ No } & \multirow{2}{*}{ Test } & & \multicolumn{6}{|c|}{ Frequency } & \multirow{2}{*}{ Score } \\
\hline & & & 1 & 2 & 3 & 4 & 5 & 6 & \\
\hline \multirow{2}{*}{1} & \multirow{2}{*}{$\begin{array}{l}\text { Pre- } \\
\text { Test }\end{array}$} & $\mathrm{F}$ & 6 & 72 & 261 & 57 & 24 & 0 & 420 \\
\hline & & $\%$ & 1 & 17 & 62 & 14 & 6 & 0 & 100 \\
\hline \multirow{2}{*}{2} & \multirow{2}{*}{$\begin{array}{l}\text { Post } \\
\text { Test }\end{array}$} & $\mathrm{F}$ & 0 & 17 & 48 & 256 & 99 & 0 & 420 \\
\hline & & $\%$ & 0 & 4 & 11 & 61 & 24 & 0 & 100 \\
\hline
\end{tabular}

Table II shows the mean score students moral cognitive tests. This data is presented with the intent to see the tendency of the moral cognitive stage of the learner seen from the mean score. While Table III is a tendency of moral cognitive test score of 
learners seen from the percentage. There are 6 stages of moral cognitive development developed by Kohlberg [11] that is stage I orientation to obedience and punishment, stage II orientation to Needs Satisfaction, stage III orientation to Image of "Good Child", stage IV orientation pay attention to law and regulation, stage $\mathrm{V}$ orientation taking into account the rights of Individuals and stage VI Taking into account universal ethical principles.

Table III shows that the mean value of cognitive moral of learners has increased in the BKMT learning model. The moral cognitive pretest scores in the limited test learners of 3.04 mean that the cognitive tendency of the learners moral is in stage III that is the orientation of observing law and regulation. Likewise seen from the trend based on the percentage. Table 3.2 shows that $60 \%$ of cognitive moral pretest score learners is in stage III.

A post-test score of moral cognitive in this study learners get mean score 4.04, the cognitive tendency of moral learners are at stage IV that is an orientation in law and regulation. Therefore, seen from the tendency base on the percentage. In Table III shows that $61 \%$ of students' cognitive moral pretest score is in stage IV. The Implementation of BKMT a model to enhance cognitive development students.

To understand a difference of mean before and after given treatment that is study using BKMT model paired sample t-test is done between pre-test score and post-test value in the limited test. The following are presented differences and improvement learners detail in cognitive development stages in the limited test 1 and the limited test 2 .

TABLE IV. DIFFERENCES AND INCREASING STAGE OF MORAL COGNITIVE DEVELOPMENT LEARNERS IN BKMT LEARNING MODEL

\begin{tabular}{|c|c|c|c|c|c|c|}
\hline \multirow{2}{*}{$\begin{array}{c}\text { Name of } \\
\text { Elementary } \\
\text { School } \\
\end{array}$} & \multicolumn{2}{|c|}{ Treatment } & \multirow{2}{*}{ Gain } & \multirow{2}{*}{$\begin{array}{c}\mathrm{N}- \\
\text { Gain } \\
\langle\mathrm{g}\rangle\end{array}$} & \multirow{2}{*}{ P-Value } & \multirow{2}{*}{ Differences } \\
\hline & Before & After & & & & \\
\hline $\begin{array}{c}\text { SD } \\
\text { Ketabang }\end{array}$ & 3.05 & 4.04 & 0.99 & 0.01 & $0,000>0.05$ & Significant \\
\hline
\end{tabular}

Based on table IV there are significant differences in the stage of moral cognitive development of learners before and after the implementation of BKMT learning model. Based on the research results obtained data that BKMT learning model is effective in improving the moral development stage of student's cognitive development. Stage of moral cognitive development of learners in experiment class is seen from the mean value and the trend of value frequency that appears to increase from phase III orientated to the image of "good child", or "good boy" and "nice girl" orientation to stage IV of participants' moral cognitive development students are orienting to laws and regulations. The development of cognitive morals is characterized by changes in reasoning, feelings, and behavior about standards of right and wrong. The intrapersonal dimension in moral development regulates someone activity when it engages in social interactions and interpersonal dimensions that govern social interaction and conflict resolution [2], [7], [8]

The steps of the BKMT learning model effectively fosters empathy, self-control, respect, kindness, tolerance, and fairness in learners. These virtue values grow and are well honed to the learner in the face moral conflicts, especially the moral conflicts that occur and are encountered in the immediate environment. [22] Step 1, understanding the problems faced in the moral conflicts of sharpening the empathy of learners to understand the problem correctly. Step 2, determine the action to be taken and determine the reasons underlying the action, sharpen the attitude or ability to use the conscience, kindness, and justice of learners to do the best and be fair and respect others. Next, step 3, examine the choice of actions and the reasons chosen, honing the ability of kindness, empathy, using conscience, tolerance and fairness and self-control of learners against the diversity of interpretation and argumentation of moral considerations that arise. And step 4, describes the position of each honing the attitude of justice of learners so as to have respect and confidence in the choice of self, others, and the surrounding community.

It is these attitudes that ultimately shape the moral intelligence and positive self-concept for learners in view of themselves and their environment [22], [23]. The moral intelligence helps learners to understand what is right and wrong in taking an action or behave so that learners have a strong moral belief in acting on that belief and being right and honorable [24]. The moral intelligence that helps learners to face the inevitable challenge and moral pressure in his life later, and it will save the learners to stay there the right path and help him to always be moral in the action.

The BKMT learning model provides comprehensive understanding and knowledge to learners to recognize situations that occur in a moral conflict encountered. Fostering the skills of learners to make decisions about behavioral choices that will be made on situations or conflict moral encountered, and reveal the logical reasoning of a moral behavior performed [23]. In addition to training learners to recognize and accept opinions about the logical reasoning of a behavior, to know and accept opinions about the logical reason higher than the moral stages of a behavior, and able to evaluate and reflect moral values taken along with the reason so it can be accountable for all the actions.

The steps of the BKMT learning model can improve the moral reasoning ability (cognitive process) of learners in dealing with situations or conflict moral. The steps of the BKMT learning model also foster moral management in reasoning and moral decision-making by using empathy, conscience, selfcontrol, respect, kindness, tolerance and fairness in any decisionmaking over actions taken in relation to the moral decisions it takes. According to Kohlberg [24], reasoning or moral thinking is the determining factor that gave birth to moral behavior. The BKMT learning model trains the learner to understand and discover moral behavior by prioritizing skills / using his reasoning. That is, the moral behavior taken is not simply based on visible moral behaviors (value displays), but based on moral reasoning or reasons underlying such moral behavior decisions [23], [25]

Overall BKMT model activities encourage learners to feel, learn, experience and think about moral values in everyday life. BKMT learning materials (based) facts or phenomena presented can be received with certain logic or reasoning. Thus, the materials and activities in the BKMT learning model increase the scientific skills of learners in using moral values in their daily activities so that learners can see the effects of their behaviors and choices and make environmentally conscious decisions. 
In the BKMT learning model, educators are encouraged to "deliberate" through learning techniques to cultivate attitude, spiritual, and social competence (KI-1 and KI-2), by presenting a variety of experience activities in the form of reflective, visual and visual activities to help learners use their creativity and their talents, communication activities that teach learners to implement peaceful social skills, art activities, songs, and movements to inspire learners to express themselves while experiencing live values, game activities and discussions, engaging learners to think and to have fun; the time of discussion that follows this activity helps learners explore the effects of different attitudes and behaviors, imagination activities, invites learners to visualize in making values more relevant to learners, as well as self-development activities and other activities that are able to develop awareness of personal and social responsibilities, and able to be fair.

A series of learning activities through various means is expected to develop moral values. In addition, the use of stories, songs, and games from indigenous culture of Indonesia to illustrate the moral values close to the lives of learners. The series of activities also emphasized the development of selfesteem and tolerance and creative thinking [7]. Activities in the BKMT learning model are designed so that the moral cognitive of learners develop gradually in a hierarchy (from one stage to the next). An increase in reasoning, feelings, and behavior about standards about right and wrong. In addition, the skills or skills of learners increase in assessing the good and bad as well as things that can be done and should not be done [22].

Promoting active participation of learners in seeking, processing, and using knowledge to improve or develop moral reasoning. And the promoting ability of learners in understanding and choosing moral values, personal, social, and spiritual in daily life; both at school, family, and community. In order to learners have a good personal life (satisfying) and have family and community relationships. The introduction and cultivation of moral values are becoming an increasingly increasing ability in the attitude (spiritual and social), the knowledge and skills necessary for life and for society, nationhood, and contributing to the welfare of human life.

Learning by the BKMT learning model invites learners to construct their moral values, to present and do moral judgments not passively carry out the available scripts, but they creatively construct, produce, reproduce, present, and do moral judgment in themselves [14], [15]. And it is the duty of educators to not only convey good values to learners but to stimulate the sense of justice in the learners [10]. It takes the commitment and consistency of all parties to actively and continuously train and develop the learner's ability to understand the suffering of others and not to do evil, to control encouragement and delay gratification, listen to various parties before giving judgment, accept and appreciate differences, unethical, and able to empathize, fight for justice, and the ability of learners to show affection and respect for others. These abilities will shape learners to have strong character and good citizenship.

\section{CONCLUSION}

Moral Cognitive-based learning model in the integrated thematic curriculum (K-13) in Elementary School to improve the stage of moral cognitive development of learners applied can improve from stage 3 that is an orientation of the Image of "Good Boy" to stage 4 that is Taking into account the laws and regulations. The development of cognitive morals is characterized by changes in reasoning, feelings, and behavior about standards about right and wrong. The intrapersonal dimension in moral development regulates activities, someone when it engages in social interactions and interpersonal dimensions that govern social interaction and conflict resolution. Learning by the BKMT learning model invites learners to construct their moral values, present and perform moral judgments not passively carry out the available scripts, but they creatively construct, produce, reproduce, present, and do moral judgment in themselves [14], [15]. And this is the duty of educators to not only convey good values to learners but can stimulate the sense of justice in the learners so that it becomes a good citizen

\section{REFERENCES}

[1] Kohlberg, Lawrence. Tahap-Tahap Perkembangan Moral. Yogyakarta: Kanisius. 1995. P. 29

[2] Anna Laura; Gielen, Uwe P (1995) Moral reasoning and prosocial action in Italian culture Comunian. The Journal of Social Psychology; Dec 1995; 135, 6; ProQuest Sociology pg. 699. The Journal of Social Psychology, 1995, 135(6), 699-706

[3] Boyd, Dwight R. An Interpretation of Principled Morality, Journal of Moral Education, 8:2, 110-123, DOI: 10.1080/0305724790080205. 2014.

[4] Lumpkin, A. (2008), Teacher As Role Model Teaching Character and Moral Virtues, Journal of Physical Education, Recreation and Dance (JOPERD), 79(2), 45-49

[5] Althof, Wolfgang \& Berkowitz*, Marvin W. Moral education, and character education: their relationship and roles in citizenship education, Journal of Moral Education, 35:4, 495-518, DOI: 10.1080/03057240601012204. 2006.

[6] Ísaksson, Andri. Kohlberg's Theory of Moral Development and Its Relevance to Education, Scandinavian Journal of Educational Research, 23:2, 47-63, DOI: 10.1080/0031383790230202. 2015.

[7] Colby, Anne. 2000. The place of moral interpretation and habit in moral development. ProQuest Biology Journals pg. 161 / Human Development; May/Jun 2000; 43, 3;

[8] Santrock, J.W. 2011. Psikologi Pendidikan. Terjemahan Tri Wibowo B.S. Educational Psychology. 2004. Jakarta: Kencana.

[9] Fechter, Anne-Meike. 'The good child': Anthropological perspectives on morality and childhood, Journal of Moral Education, 43:2, 143-155, DOI: 10.1080/03057240.2014.909350. 2014.

[10] Hardiman, B. 1987. Pendidikan Moral Sebagai Pendidikan Keadilan. Yogyakarta: Basis "Andi Offset".

[11] Liebert, Robert M. Apa yang Berkembang dalam Perkembangan Moral, dalam Kurtines, William M. and Jacob L. Gerwitz. Moralitas, Perilaku Moral, dan Perkembangan Moral. Jakarta: UI Press. 1992. P.287

[12] Choudhuri, Mohammad. Emphasizing Morals, Values, Ethics, And Character Education In Science Education And Science Teaching. The Malaysian Online Journal of Educational Science 2016 (Volume4 - Issue 2 ). 2016.

[13] Depdikbud Modul PLPG HO-1.1. Konsep Kurikulum I. Jakarta. 2013. P.14

[14] Berger, Peter L. Kabar Angin dari Langit: Makna Teologi dalam Masyarakat Modern. Jakarta: LP3ES. 1991. 
[15] Berger, Peter L. Langit Suci: Agama sebagai Realitas Sosial. Jakarta: LP3ES. 1994.

[16] Berger, Peter L. dan Thomas Luckmann. Tafsir Sosial atas Kenyataan: Risalah tentang Sosiologi Pengetahuan. Jakarta: LP3ES. 1990.

[17] Goffman, Erving. The Presentation of Self In Everyday Life. New York: Doubleday Anchor. 1959. p.210 p. 211

[18] Budiyono, Sunu Catur. Identitas Etnik dalam Masyarakat Multietnik di Banyuwangi. Disertasi. Universitas Airlangga. 2009. P.78

[19] Dimitrov, M.D., dan Philip D. R. Jr (2003), Pretest-pos-test Designs and measurement of change, Work 20, 159-165.

[20] Kohlberg, L. \& Hersh, R. (1977) Moral development: a review of the theory, Theory Into Practice, 16(2), 53-59.

[21] Santrock, J.W. Psikologi Pendidikan. Terjemahan Tri Wibowo B.S. Educational Psychologi. 2004. Jakarta: Kencana. 2011.

[22] Jana Dvokakova, Mojmir Tyrlik, 2007:167. Effect Of Values On Responsibility Perceived In Moral Action. Studia Psychologica, 49, 2007, 2 (167).

[23] Jones, C; McNamee Mike. 2000:699. Moral reasoning, moral action, and the moral atmosphere of sport . Education and Society; Oct 2000; 5, 2; ProQuest Sociology pg. 131. Sport, Education, and Society, Vol. 5, No. 2, pp. 131-146, 2000.

[24] Lisa d. Bendixen Gregory schraw Michael e. Dunkle. 1998. Epistemic Beliefs and Moral Reasoning. ProQuest Nursing\& Allied Health Source pg. 187. The Journal of. Psychology. 1998. 132(2), 187-200

[25] Vauclair, Christin-Melanie, Wilson Marc \& Fischer Ronald. Cultural conceptions of morality: Examining laypeople's associations of moral character, Journal of Moral Education, 43:1, 54-74, DOI: 10.1080/03057240.2013.873365. 2014. 